\title{
The evaluation of the retinal findings in the fundoscopic examination of the preeclampsia patients
}

\author{
Mustafa Kalaycı' ${ }^{1}$, Özgür Şahin² \\ ${ }^{1}$ Department of Ophthalmology, Somalia Mogadishu-Turkey Training and Research Hospital, Mogadishu, Somalia \\ 2Department of Obstetrics and Gynecology, Somalia Mogadishu-Turkey Training and Research Hospital, Mogadishu, Somalia
}

\begin{abstract}
Objective: We aimed to evaluate and compare the retinal findings of the fundoscopic examination of mild and severe preeclampsia cases in our study.

Methods: The data of 165 patients who admitted to Somalia Mogadishu-Turkey Training and Research Hospital, were hospitalized in the obstetrics and gynecology clinic upon the preeclampsia diagnoses and for whom the eye consultation was requested between January 2017 and January 2020 were evaluated retrospectively. The patients were grouped according to their age, week of gestation, delivery type (cesarean section - normal delivery) and preeclampsia severity (mild - severe). The patients found to have hypertensive retinopathy changes on right or left eye or both eyes were recorded as positive in terms of the findings.

Results: While no pathological finding was observed in 104 (63.1\%) of 165 patients who underwent fundoscopic examination, 61 (36.9\%) patients had retinal pathology. Of the patients found to have pathology in their fundoscopic findings, 39 (63.9\%) were severely preeclamptic and $22(36.1 \%)$ were mildly preeclamptic. The pregnancy of 51 $(83.6 \%)$ of these 61 patients was terminated at preterm period $(<37$ weeks of gestation) and of 10 (16.4) at term ( $\geq 37$ weeks of gestation). Of 61 patients found to have retinal pathology, $36(59 \%)$ had hypertensive retinopathy, 9 (14.8\%) had macular edema, 6 (9.8\%) had hypertensive hemorrhage, 4 (6.6\%) had pigment epithelial detachment, $2(3.3 \%)$ had bilateral retinal detachment, 2 (3.3\%) had left retinal detachment, and $2(3.3 \%)$ had edema in bilateral optical disk.

Conclusion: While visual complaints are very common in preeclamptic pregnant women, rare but serious complications such retinal detachment, pigment epithelial detachment, macular edema and papilledema as may also develop. Other retinal diseases in addition to hypertensive retinopathy should also be considered during the fundoscopic examination of preeclamptic pregnant women. The clinicians should be aware of these ocular indications and they should work in cooperation to prevent blindness during or after pregnancy. It seems that terminating the pregnancy in preeclamptic pregnant women who develop visual impairment is effective to regain visual capability.
\end{abstract}

Keywords: Retinal detachment, pregnancy, hypertension, preeclampsia.
Özet: Preeklampsi hastalarının göz dibi muayenesinde retina bulgularının değerlendirilmesi

Amaç: Bu çalışmada amaç, hafif ve şiddetli preeklampsi hastalarının göz dibi retinal bulgularını değerlendirmek ve karşılaştırmaktir.

Yöntem: Ocak 2017 - Ocak 2020 tarihleri arasında Somali Mogadişu-Türkiye Eğitim ve Araştırma Hastanesi'ne başvuran ve preeklampsi tanısıyla kadın hastalıkları ve doğum servisine yatışı gerçekleştirilip göz konsültasyonu istenen 165 hastanın verileri retrospektif olarak değerlendirildi. Hastalar yaş, gestasyon haftası, doğum tekniği (sezaryen - normal doğum) ve preeklampsinin seviyesine (hafif - şiddetli) göre sinıflandırıldı. Sağ veya solda veya her iki gözde hipertansif retinopati değişiklikleri izlenen hastalar, bulgular açısından pozitif olarak kaydedildi.

Bulgular: Göz dibi muayenesi yapılan 165 hastanın 104'ünde (\%63.1) patolojik bulgu gözlenmezken, 61 (\%36.9) hastada retinal patoloji gözlenmiştir. Göz dibi bulgularında patoloji saptanan hastaların 39'u (\%63.9) şiddetli preeklamptik, 22'si (\%36.1) hafif preeklamptikti. Bu 61 hastadan 51'inin (\%83.6) gebeliği preterm (<37. gestasyonel hafta), 10'unun (\%16.4) ise term ( $\geq 37$. gestasyonel hafta) olarak sonlandırılmıştı. Retinal patoloji saptanan 61 hastanın 36 'sında (\%59) hipertansif retinopati, 9'unda (\%14.8) maküla ödemi, 6'sında (\% 9.8) hipertansif hemoraji, 4'ünde (\% 6.6) pigment epitel dekolmanı, 2'sinde (\%3.3) bilateral retina dekolmanı, 2'sinde (\%3.3) sol retina dekolmanı, 2'sinde de (\%3.3) bilateral optik diskte ödem izlendi.

Sonuç: Preeklampsi olan gebelerde görsel şikayetler çok yaygın olmakla birlikte retina dekolmanı, pigment epitel dekolmanı, maküla ödemi ve papilla ödemi gibi nadir fakat ciddi komplikasyonlar da ortaya çıkabilir. Preeklamptik gebelerin fundus muayenesi esnasında hipertansif retinopati dışında diğer retinal hastalıklar da akılda tutulmalıdır. Klinisyenler bu oküler belirtilerin farkında olmalı ve gebelikte veya sonrasında oluşabilecek körlükleri engellemek için iş birliği içinde çalışmalıdır. Görme kaybı gelişen preeklamptik gebede, gebeliğin sonlandırılması görmenin yeniden kazanılmasında etkili görünmektedir.

Anahtar sözcükler: Retina dekolmanı, gebelik, hipertansiyon, preeklampsi.

Correspondence: Mustafa Kalayc1, MD. Department of Ophthalmology, Somalia Mogadishu-Turkey Training and Research Hospital, Mogadishu, Somalia. e-mail: drkalayci07@hotmail.com / Received: March 27, 2020; Accepted: May 19, 2020

Please cite this article as: Kalaycı M, Şahin Ö. The evaluation of the retinal findings in the fundoscopic examination of the preeclampsia patients. Perinatal Journal 2020;28(2):62-67. doi:10.2399/prn.20.0282004 


\section{Introduction}

Preeclampsia is a pregnancy-specific disease which affects $5-7 \%$ of pregnancies, develops during second or third trimester, and causes fetal mortality rate to increase significantly. ${ }^{[1]}$ Measuring blood pressure before pregnancy and during early period and second trimester of pregnancy is very important in terms of the preeclampsia diagnosis. Although elevated blood pressure and the presence of proteinuria developing after 20 weeks of gestation in a pregnant woman who is considered to be normotensive before pregnancy are defined as preeclampsia, the presence of proteinuria is not always necessary. ${ }^{[2,3]}$ Preeclampsia diagnosis can also be established in case of systemic findings (such as liver dysfunction, renal failure, pulmonary edema, presence of hemolysis and thrombocytopenia, and visual and cerebral findings) coexisting with hypertension in the absence of proteinuria. ${ }^{[3]}$ Preeclampsia affects all organs and systems including visual system. It causes ischemic injury by leading to maternal systemic inflammation and endothelial dysfunction. ${ }^{[4]}$

The vision system may be affected at different levels in the preeclampsia. Various underlying pathological changes in retina, optical nerve and cerebral cortex cause ocular symptoms developing in the patients. ${ }^{[5]}$ The most common ocular pathological change is the vasoconstriction of arterioles. Serous retinal detachment developing as a result of choroidal vascularization is a rare reason of visual impairment in preeclampsia. ${ }^{[6]}$

The visual symptoms may include photopsia, hemianopsia, difficulty in focusing, blurry vision, reduced visual acuity and full blindness in severe cases. ${ }^{[7]}$ It has become obligatory to have an ophthalmoscope in delivery rooms according to the efficiency in-place evaluation of obstetrics and pediatrics hospital published in 2018. ${ }^{[8]}$ The recent studies have shown that the women with the history of preeclampsia are under a higher risk of ocular complication during antepartum, intrapartum and postpartum periods compared to the health pregnant women. ${ }^{[9,10]}$ Although most of the ocular changes are physiological (reduced intraocular pressure, increased myopia, bitemporal and concentric defects in the visual field associated with the physiological growth in pituitary gland) during pregnancy, they can be pathological (papilledema, optic atrophy, retinal hemorrhage, macular edema, retinal detachment) in preeclampsia. ${ }^{[8]}$ In addition, preeclamptic retinopathy may present more severely in the presence of underlying diabetes, chronic hypertension and kidney disease. ${ }^{[8]}$

Somalia is a country with low income which is bordered by Kenya, Ethiopia and Djibouti and located in Sub-Saharan Africa. The fertility rate in Somalia is 6.08 births per woman (2014 estimates). This is also the fourth highest rate in the world. The limited access to antenatal care services in underdeveloped and developing countries increases the rates of sequela and mortality rates associated with preeclampsia and its complications. $^{[11]}$

In this study, we aimed to evaluate the fundoscopic findings of the pregnant women who were hospitalized in the Obstetrics and Gynecology Clinic of Somalia Mogadishu-Turkey Training and Research Hospital due to the preeclampsia diagnosis in the last 3 years.

\section{Methods}

The files of 220 patients who were established with the diagnosis of preeclampsia and delivered at the Obstetrics and Gynecology Clinic of Somalia Mogadishu-Turkey Training and Research Hospital, and for whom the eye consultation was requested during the hospitalization between January 2017 and January 2020 were evaluated retrospectively. The fundoscopic examination findings of 165 of these patients were accessed. The approval was obtained from the Ethics Committee of Somalia Mogadishu-Turkey Training and Research Hospital for the study (Approval No. 218: MSTH/3401, Date: 12.02.2020). The study was conducted in accordance with the principles of Helsinki Declaration.

The diagnosis of preeclampsia was established according to the criteria of the American College of Obstetricians and Gynecologists (ACOG). ${ }^{[12]}$ According to these criteria, (1) the presence of $140-159 \mathrm{mmHg}$ or higher persistent systolic blood pressure or 90-109 $\mathrm{mmHg}$ or higher diastolic blood pressure after 20 weeks of gestation in a woman whose blood pressure is within normal limits previously, (2) measuring blood pressure $160 / 110 \mathrm{mmHg}$ or higher with a 15 -minute interval together with systemic findings (proteinuria $\geq 300$ $\mathrm{mg} / 24$-hour, platelet count $<100,000 / \mathrm{dL}$, at least two times higher transaminase level, creatinine level $>1.1$ $\mathrm{mg} / \mathrm{dL}$, presence of pulmonary edema, and presence of cerebral or visual symptoms) and (3) measuring blood pressure $\geq 160 / 110 \mathrm{mmHg}$ with 4-hour interval in addition to at least one systemic finding was considered 
preeclampsia. The diagnosis of HELLP syndrome was established when it is found that a preeclamptic patient has hemolysis, lactate dehydrogenase (LDH) $>600 \mathrm{IU} / \mathrm{L}$ and platelet count $<100,000 \mathrm{cell} / \mathrm{mm}^{3}$. The cases found to have new-onset grand mal seizure were considered eclampsia.

The ocular symptoms of consulted cases were (1) blurry vision, (2) headache, (3) photopsia, (4) hemianopsia, (5) difficulty in focusing, (6) reduced visual acuity and (7) full loss of vision in both eyes.

The patients were examined by direct and/or indirect ophthalmoscope at bedside half an hour later after applying $1 \%$ tropicamide drop on both eyes.

The patients were grouped according to their age, week of gestation, delivery type (cesarean section - normal delivery) and preeclampsia severity (mild - severe). The patients found to have hypertensive retinopathy changes on right or left eye or both eyes were recorded as positive in terms of the findings.

Hypertensive retinopathy was categorized according to Keith-Wagener classification. According to this classification:

- Grade 1: Mild generalized retinal arteriolar narrowing;

- Grade 2: Definite focal arteriolar narrowing and arteriovenous nipping in addition to the Grade 1 findings;

- Grade 3: Retinal hemorrhages, exudates and cottonwool spots in addition to the Grade 2 findings;

- Grade 4: The presence of papilledema in addition to the Grade 3 findings. ${ }^{[13]}$

The patients with pregestational hypertension, diabetes and kidney disease and the patients with an eye disease preventing fundus imaging (corneal scar and dystrophies, cataract, etc.) were excluded from the study.
Table 1. Demographic and clinical characteristics of preeclamptic patients.

\begin{tabular}{lc} 
Characteristics & Mean value (min-max) \\
\hline Maternal age (year) & $24.4 \pm 5.2(15-44)$ \\
Week of gestation & $33 \pm 4.2(26-38)$ \\
Systolic pressure $(\mathrm{mmHg})$ & $161 \pm 11.4(140-185)$ \\
Diastolic pressure $(\mathrm{mmHg})$ & $102 \pm 8.8(90-115)$ \\
Protein (mg/day) & $2204 \pm 254(1300-3300)$ \\
\hline
\end{tabular}

For the statistical analyses, IBM SPSS 23.0 (SPSS Inc., Chicago, IL, USA) software was used. The analyses were done by Fisher's exact test and the value $\mathrm{p}<0.05$ considered statistically significant.

\section{Results}

Of the patients established with preeclampsia diagnosis, the mean age was $24.4 \pm 5.2$ (range: $15-44$ ) years and mean week of gestation was $33 \pm 4.2$ (range: 26-38) weeks. While the mean arterial blood pressure was 153/98 $\mathrm{mmHg}$ in the patients with mild preeclampsia, it was $178 / 110 \mathrm{mmHg}$ in the patients with severe preeclampsia. The mean proteinuria amount in 24-hour urine was $2204 \pm 254 \mathrm{mg} / \mathrm{l} /$ day (Table 1).

Of 165 patients, the pregnancy was terminated at preterm period ( $<37$ weeks of gestation) in $91(55.1 \%)$ patients and at term ( $\geq 37$ weeks of gestation) in 74 (44.9\%) patients. Fifty-seven $(34.5 \%)$ patients had severe preeclampsia and $108(65.5 \%)$ patients had mild preeclampsia. While 118 (71.5\%) patients delivered by cesarean section, 47 (28.5\%) patients delivered by 7 spontaneous vaginal labor.

Fourteen $(8.4 \%)$ of all cases were previously using alpha-methyldopa $(250 \mathrm{mg}) 3 \times 1$ tablet as an antihypertensive drug due to the preeclampsia diagnosis.

Table 2. The distribution of retinal findings in preeclamptic patients.

\begin{tabular}{lcccc} 
Retinal finding & Mild preeclampsia & Severe preeclampsia & Total & p-value \\
Hypertensive retinopathy & 16 & 20 & 36 & 0.24 \\
Hypertensive hemorrhage & 2 & 4 & 6 & 0.37 \\
Retinal detachment & 1 & 3 & 4 & $<0.05$ \\
Pigment epithelial detachment & 1 & 3 & 4 & $<0.05$ \\
Macular edema & 2 & 7 & 9 & $<0.05$ \\
Papilledema & 0 & 2 & 2 & - \\
\hline
\end{tabular}


The most common complaints of the consulted patients were headache, blurry vision and eye floaters, respectively.

While no pathological finding was found in 104 (63.1\%) of 165 preeclamptic pregnant women who underwent fundoscopic examination, retinal pathology was observed in $61(36.9 \%)$ preeclamptic pregnant women. Thirty-nine $(63.9 \%)$ of the patients found to have pathology in their fundus findings had severe preeclampsia while $22(36.1 \%)$ of them had mild preeclampsia. The pregnancy of $51(83.6 \%)$ patients was terminated at preterm period ( $<37$ weeks of gestation) and $10(16.4 \%)$ of them at term ( $\geq 37$ weeks of gestation).

Of 61 preeclamptic pregnant women found to have retinal pathology, 36 (59\%) had hypertensive retinopathy, 9 (14.8\%) had macular edema, 6 (9.8\%) had hypertensive hemorrhage, 4 (6.6\%) had pigment epithelial detachment, 2 (3.3\%) had bilateral retinal detachment, $2(3.3 \%)$ had left retinal detachment, and $2(3.3 \%)$ had edema in bilateral optical disc (Table 1). Macular edema, retinal detachment and pigment epithelial detachment were more frequent in the severe preeclamptic cases than the mild preeclamptic cases, and it was statistically significant $(\mathrm{p}<0.05)$ (Table 2$)$.

When 61 preeclamptic pregnant women who had retinal pathology were evaluated among themselves, 9 $(14.8 \%)$ patients in the severe preeclampsia group were followed up in the intensive care unit after labor due to HELLP syndrome. The convulsion was observed in 2 $(3.3 \%)$ patients. The uterine atony developed in 1 $(1.6 \%)$ patient during the cesarean section, and it was seen in the follow-up that the patient developed acute renal failure. One (1.6\%) patient who developed lung edema after right ventricular failure died.

Of the patients diagnosed with hypertensive retinopathy, $22(50 \%)$ were grade $1,14(31.9 \%)$ were grade 2, $6(13.6 \%)$ were grade 3 and $2(4.5 \%)$ were grade 4 (Table 3).

Table 3. The distribution of hypertensive retinopathies by grade.

\begin{tabular}{lcc} 
Hypertensive retinopathy grade & Patient number & Percentage (\%) \\
\hline Grade 1 & 22 & 50 \\
Grade 2 & 14 & 31.9 \\
Grade 3 & 6 & 13.6 \\
Grade 4 & 2 & 4.5 \\
Total & 44 & 100 \\
\hline
\end{tabular}

\section{Discussion}

The preeclampsia, which is a constrictive vasculopathy, is a major reason for maternal and neonatal morbidity and mortality, and it is estimated that visual systems of $30-100 \%$ of preeclamptic women are affected. ${ }^{[14]}$ Preeclampsia is seen about $5 \%$ of the pregnant women, and ocular complications have been reported in one third of these patients. ${ }^{[15]}$ The blurred vision is the most common complaint in these patients. ${ }^{[16]}$ On the other hand, photopsia, scotoma and diplopia are not rare. ${ }^{[17]}$ These findings are observed after the development of hypertensive retinopathy and optic neuropathy associated with the hyperperfusion of the ocular system. However, there are studies reporting that approximately $40 \%$ of the blurred vision complaint of preeclamptic patients are subjective. ${ }^{[18]}$ In our study, the rate of affected visual system in preeclamptic pregnant women was $36.9 \%$. While the blurred vision was the most common complaint, eye floater and temporary loss of vision were not rare.

The retinopathy findings in preeclamptic patients are similar to the hypertension-associated retinopathy. The retinopathy beginning with the generalized weakening of retinal arterioles followed by focal narrowing is the most common finding in the preeclamptic retinopathy. ${ }^{[19]}$

In our study, we found hypertensive retinopathy in $59 \%$ of the patients whose visual systems were affected, and it was also the most common finding. Fifty percent of the hypertensive retinopathies was grade 1 .

Retinal edema, hemorrhage and exudate, nerve fiber infarcts and neovascularization-associated vitreous hemorrhage and serous retinal detachment are the other pathological changes seen in preeclampsia-associated retinopathy ${ }^{[19,20]}$ Endothelial injury, abnormal autoregulation and hypoperfusion-associated ischemia are among the potential reasons of these complications. Most of these findings return to normal levels after the recovery from preeclampsia.

The recent studies reported the prevalence of retinal detachment in preeclampsia between $1.5 \%$ and $3.7 \% .{ }^{[21]}$ In our study, this rate was $6.6 \%$. The retinal detachment is an extraordinary reason of visual loss in preeclampsia. It is usually in bilateral, serous and bullous form. The detachment of neurosensorial retina from retinal pigment epithelium due to severe hypertension causes the loss of vision. The treatment of retinal detachment in preeclampsia is conservative and it includes the treatment of underlying condition. The prognosis is good, and 
spontaneous resolution generally occurs by blood pressure control and labor. The development of retinal detachment in a preeclamptic pregnancy is an indication for the necessity of pregnancy termination. ${ }^{[22]}$ After labor, the sub-retinal fluid is resorbed and visual acuity becomes normal within weeks. On the other hand, if there is excessive necrosis in the retinal pigment epithelium, permanent loss of vision may occur. ${ }^{[23]}$ Lee et al. reported that ocular symptoms and visual sequelas usually become reversed with the immediate termination of the pregnancy. ${ }^{[24]}$ In our study, we observed that the retinal detachments of the patients, who were followed up after labor, recovered without the need of surgical procedure. The findings of the patients with pigment epithelial detachment also returned to normal levels during the follow-up. The reason for a higher rate of retinal detachment in our study compared to other countries may be that pregnant women did not undergo routine health screening before pregnancy in Somalia and they admitted to hospital upon pregnancy for the first time. In addition, not performing fundoscopic examination routinely during pregnancy may lead to miss out retinal breaks and small peripheral ruptures. According to our observations, the greatest obstacle for the routine screenings is that the country does not have a social healthcare system and the people cannot afford healthcare costs as their income level is low. In addition, maternal morbidity and mortality and perinatal morbidity and mortality may progress severely in the preeclampsia developing in association with chronic hypertension. ${ }^{[25]}$ Not doing routine examinations before the development of preeclampsia in most of the pregnant women in Somalia may lead to miss out hypertensive pregnant women and make preeclampsia complications more frequent and severe.

The retinopathy grade correlates with preeclampsia grade positively. ${ }^{[26]}$ Radha Bai Prabhu showed in their study that retinal detachment and loss of vision are more frequent in the patients with severe preeclampsia. ${ }^{[2]}$ Retinal findings being more frequent in severe preeclampsia and observing retinal detachment more frequently in the patients with severe preeclampsia particularly in our study were consistent with their study.

Pigment epithelial detachment accompanying to central serous chorioretinopathy is detachment of neurosensorial layer after the subretinal fluid accumulation on the posterior part of fundus. There are studies showing that this risk increases up to 9 times during third trimester in particular. ${ }^{[2]}$ The increasing cortisol level in the blood circulation particularly during third trimester causes this condition. ${ }^{[14]}$ In our study, we consider that the development of pigment epithelial detachment may be associated with elevated blood pressure because 3 out of 4 cases with pigment epithelial detachment are severe preeclampsia cases.

The loss vision caused by the cortex part of optical paths can be seen rarely in preeclampsia cases. ${ }^{[28]}$ Ischemia, edema and hemorrhage are among the reasons of cortical loss of vision, and they are usually irreversible. Permanent damage at legal blindness level may develop in 1-3\% of the patients with preeclampsia/eclampsia. ${ }^{[2]}$ There was no patient with acute cortical blindness in our study.

\section{Conclusion}

It seems that the greatest obstacle for the regular follow-up of pregnant women in the underdeveloped countries such as Somalia is the incapability of public healthcare organizations and the low income levels. Making free and accessible pregnant follow-up centers more prevalent may decrease the severity and frequency of maternal complications.

Retroorbital evaluations should be made in preeclamptic patients describing loss of vision even though pupil reflex and fundus findings are normal. Therefore, it may be helpful to do examinations by MRI (magnetic resonance imaging) and VEP (visual evoked potential) devices for lesions associated with optic nerve and occipital cortex in addition to direct ophthalmoscope for the preeclamptic pregnant women developing loss of vision.

Although visual complaints are very common in preeclamptic pregnant women, rare but serious complications such as retinal detachment, pigment epithelial detachment, macular edema and papilledema may also develop.

Other retinal diseases should also be kept in mind in addition to the hypertensive retinopathy during the fundoscopic examination of the preeclamptic pregnant women. The clinicians should be aware of these ocular indications and work in cooperation to prevent blindness that may develop during or after pregnancy. It seems that terminating the pregnancy in preeclamptic pregnant women who develop loss of vision is effective to regain visual capability.

Conflicts of Interest: No conflicts declared. 


\section{References}

1. Mol BWJ, Roberts CT, Thangaratinam S, Magee LA, De Groot CJM, Hofmeyr GJ. Pre-eclampsia. Lancet 2016;387 (10022):999-1011. [PubMed] [CrossRef]

2. Başol G, Uzun ND, Uzun F, Kale A, Terzi H. Retrospective analysis of the preeclampsia cases delivered in our clinic between 2013 and 2017. Perinatal Journal 2018;26:135-40. [CrossRef]

3. American College of Obstetricians and Gynecologists; Task Force on Hypertension in Pregnancy. Hypertension in pregnancy. Report of the American College of Obstetricians and Gynecologists' Task Force on Hypertension in Pregnancy. Obstet Gynecol 2013;122:1122-31. [PubMed] [CrossRef]

4. Weel CI, Romão-Veiga M, Matias ML, Fioratti EG, Peraçoli JC, Borges VT, et al. Increased expression of NLRP3 inflammasome in placentas from pregnant women with severe preeclampsia. J Reprod Immunol 2017;123:40-7. [PubMed] [CrossRef]

5. Arpacı H, Koban Y, Tok A, Beyoğlu A. Ocular perfusion pressure and intraocular pressure in pregnant women with severe preeclampsia. Ginekol Pol 2018;89:513-7. [PubMed] [CrossRef]

6. Mackensen F, Paulus WE, Max R, Ness T. Ocular changes during pregnancy. Dtsch Arztebl Int 2014;111:567-76. [PubMed] [CrossRef]

7. Garg A, Wapner RJ, Ananth CV, Dale E, Tsang SH, Lee W, et al. Choroidal and retinal thickening in severe preeclampsia. Investig Ophthalmol Vis Sci 2014;55:5723-9. [PubMed] [CrossRef]

8. T.C. Sağlık Bakanlığı Kamu Hastaneleri Genel Müdürlüğü Să̆lık Hizmetleri Dairesi Başkanlığı. Kadın doğum ve çocuk hastalıkları hastanesi verimlilik yerinde değerlendirme rehberi 2018. [nternet] Available from: https://khgmsaglikhizmetleridb. saglik.gov.tr/TR,46693/kadin-dogum-ve-cocuk-hastaliklarihastanesi-verimlilik-yerinde-degerlendirme-rehberi-2018.html

9. Kvehaugen AS, Dechend R, Ramstad HB, Troisi R, Fugelseth D, Staff AC. Endothelial function and circulating biomarkers are disturbed in women and children after preeclampsia. Hypertension 2011;58:63-9. [PubMed] [CrossRef]

10. Murphy MSQ, Casselman RC, Smith GN. Postpartum alterations in circulating endothelial progenitor cells in women with a history of pre-eclampsia. Pregnancy Hypertens 2013;3: 178-85. [PubMed] [CrossRef]

11. Say L, Chou D, Gemmill A, Tunçalp Ö, Moller A-B, Daniels J, et al. Global causes of maternal death: a WHO systematic analysis. Lancet Glob Health 2014;2:e323-33. [PubMed] [CrossRef]

12. American College of Obstetricians and Gynecologists; Task Force on Hypertension in Pregnancy. Hypertension in pregnancy. Report of the American College of Obstetricians and Gynecologists' Task Force on Hypertension in Pregnancy. Obstet Gynecol 2013;122:1122-31. [PubMed] [CrossRef]

13. İnan S. Diabetik retinopati ve etiyopatogenezi. Kocatepe Tip Dergisi 2014;15:207-17.
14. Naderan M. Ocular changes during pregnancy. J Curr Ophthalmol 2018;30:202-10. [PubMed] [CrossRef]

15. Dinn RB, Harris A, Marcus PS. Ocular changes in pregnancy. Obstet Gynecol Surv 2003;58:137-44. [PubMed] [CrossRef]

16. Vigil-De Gracia P, Ortega-Paz L. Retinal detachment in association with pre-eclampsia, eclampsia, and HELLP syndrome. Int J Gynecol Obstet 2011;114:223-5. [PubMed] [CrossRef]

17. Schultz KL, Birnbaum AD, Goldstein DA. Ocular disease in pregnancy. Curr Opin Ophthalmol 2005;16:308-14. [PubMed] [CrossRef]

18. Royburt M, Seidman DS, Serr DM, Mashiach S. Neurologic involvement in hypertensive disease of pregnancy. Obstet Gynecol Surv 1991;46:656-64. [PubMed] [CrossRef]

19. Omoti AE, Waziri-Erameh JM, Okeigbemen VW. A review of the changes in the ophthalmic and visual system in pregnancy. Afr J Reprod Health 2008;12:185-96.[PubMed]

20. Bona M, Wong A. The eyes in pregnancy. Ophthalmology Rounds 2007;5(3). Available from: https://240604ab-ba80$45 \mathrm{db}-\mathrm{ba} 95-5 \mathrm{~d} 2 \mathrm{a} 48 \mathrm{c} 9 \mathrm{~d} 25 \mathrm{~b}$.filesusr.com/ugd/b076e2 Ofd2930416ef480595f8c425725669e7.pdf?index=true

21. Auger N, Fraser WD, Paradis G, Healy-Profitós J, Hsieh A, Rhéaume M-A. Preeclampsia and long-term risk of maternal retinal disorders. Obstet Gynecol 2017;129:42-9. [PubMed] [CrossRef]

22. Radha Bai Prabhu T. Serious visual (ocular) complications in pre-eclampsia and eclampsia. J Obstet Gynecol India 2017;67: 343-8. [PubMed] [CrossRef]

23. Srećković SB, Janićijević-Petrović MA, Stefanović IB, Petrović NT, Šarenac TS, Paunović SS. Bilateral retinal detachment in a case of preeclampsia. Bosn J Basic Med Sci 2011;11:129-31. [PubMed] [CrossRef]

24. Lee CS, Choi EY, Lee M, Kim H, Chung H. Serous retinal detachment in preeclampsia and malignant hypertension. Eye 2019;33:1707-14. [PubMed] [CrossRef]

25. Moussa H, Leon MG, Marti A, Chediak A, Pedroza C, Blackwell SC, et al. Pregnancy outcomes in women with preeclampsia superimposed on chronic hypertension with and without severe features. Am J Perinatol 20176;34:403-8. [PubMed] [CrossRef]

26. do Prado RS, Figueiredo EL, Magalhães TVB. Retinal detachment in preeclampsia. Arq Bras Cardiol 2002;79:183-6. [PubMed] [CrossRef]

27. Liu B, Deng T, Zhang J. Risk factors for central serous chorioretinopathy: a systematic review and meta-analysis. Retina 2016;36:9-19. [PubMed] [CrossRef]

28. Abdellaoui T, Bouayad G, Elkhoyaali A, Laaribi N, Mouzari $\mathrm{Y}$, Elasri F, et al. Bilateral serous retinal detachment complicating preeclampsia. Indian Journal of Medical Specialities 2018;9:36-9.

Bu makalenin kullanım izni Creative Commons Attribution-NoCommercial-NoDerivs 3.0 Unported (CC BY-NC-ND3.0) lisansı aracılı̆̆ıyla bedelsiz sunulmaktadır. / This work is licensed under the Creative Commons Attribution-NonCommercial-NoDerivs 3.0 Unported (CC BY-NC-ND3.0) License. To view a copy of this license, visit http://creativecommons.org/licenses/by-nc-nd/3.0/ or send a letter to Creative Commons, PO Box 1866, Mountain View, CA 94042, USA. 